\title{
EXAMINATION OF THE CHEMICAL PROPERTIES OF SEAWATER OF THE TAMBELAN ISLANDS
}

\author{
Suherman $^{1, *}$ and Hanif Budi Prayitno ${ }^{2}$ \\ ${ }^{1}$ Department of Chemistry, Faculty of Mathematics and Natural Sciences, Universitas Gadjah Mada, \\ Sekip Utara P.O. Box 21 BLS Yogyakarta 55281, Indonesia \\ ${ }^{2}$ Research Center for Oceanography, Indonesian Institute of Science, \\ JI. Pasir Putih I no. 1 Ancol Timur-Jakarta Utara 14430, Indonesia
}

Received May 23, 2012; Accepted October 30, 2012

\begin{abstract}
This research aims to investigate the quality of the Tambelan island waters as primary information to support these islands as a marine conservation area. Some chemical properties of seawater such as $\mathrm{pH}$ and DO (Dissolved Oxygen) were identified by portable instrumentations. Furthermore inorganic nutrients phosphate, nitrate, and silicate contents were measured according to the methods developed by Morris and Riley in 1963 and then modified by Strickland and Parsons in 1968. The results of the research show that the $\mathrm{pH}$ values were in the range of 8.06 to 8.30, and the DO level amounted to 5.26 to $6.31 \mathrm{mg} / \mathrm{L}$. Further results from this research show that the content of phosphate and nitrate ranged from 0.001 to $0.004 \mathrm{mg} / \mathrm{L}$ and 0.005 to $0.018 \mathrm{mg} / \mathrm{L}$, respectively. Meanwhile, the content of silicate was found to be 0.063 to $0.134 \mathrm{mg} / \mathrm{L}$ in the archipelagic waters of Tambelan. The values of the above parameters are in accordance with the range of the seawater quality as recommended by the Ministry of Environment of the Republic of Indonesia. Therefore, good water quality of the Tambelan islands provides great opportunities to be developed as a marine conservation area.
\end{abstract}

Keywords: Tambelan islands; Seawater; Chemical properties; Marine conservation area

\section{ABSTRAK}

Penelitian ini bertujuan untuk mengetahui kualitas perairan Kepulauan Tambelan sebagai informasi utama untuk mendukung kepulauan ini sebagai kawasan konservasi laut. Beberapa sifat kimia air laut seperti pH dan DO (oksigen terlarut) telah diidentifikasi dengan menggunakan instrumentasi portabel. Selanjutnya kandungan fosfat, silikat dan nitrat telah diukur dengan metode yang dikembangkan oleh Morris dan Riley pada tahun 1963 dan kemudian dimodifikasi oleh Strickland dan Parsons pada tahun 1968. Hasil penelitian menunjukkan bahwa nilai pH berada pada kisaran 8,06-8,30, dan kandungan DO ditemukan sebesar 5,26-6,31 mg/L. Selanjutnya hasil dari penelitian ini menunjukkan bahwa kandungan fosfat dan nitrat berkisar 0,001-0,004 mg/L dan 0,005-0,018 mg/L masing-masing. Sementara itu, kandungan silikat ditemukan pada kisaran 0,063-0,134 mg/L di perairan kepulauan Tambelan. Nilai-nilai parameter di atas adalah sesuai dengan kisaran kualitas air laut seperti yang direkomendasikan oleh Kementerian Lingkungan Hidup-Republik Indonesia. Oleh karena itu, kualitas air yang baik dari pulau Tambelan tersebut memberikan peluang besar bagi wilayah ini untuk dikembangkan sebagai kawasan konservasi laut (KKL).

Kata Kunci: Kepulauan Tambelan; Air laut, Sifat kimia; Kawasan konservasi laut

\section{INTRODUCTION}

South Natuna Sea area and its surroundings in nature have the potential of abundant natural resources. Due to the remote location, the influence of season which is less friendly, and exploitation activities that are using traditional means led the potential of this sea region has not been managed optimally. Marine fishery resources in this area are estimated to reach more than

* Corresponding author. Tel/Fax : +62-274-545188

Email address : suherman_ugm@yahoo.com
1 million tons per year which only $36 \%$ from the total utilization.

As a part of the Natuna sea region, the Tambelan islands waters have an important role in sustaining the life of society around who rely income from marine products. Tambelan islands located in the southern part of the Natuna sea and bordering the South China sea, including the Bintan regency, and administratively included in the province of Riau islands. Tambelan waters which are marginal seas becoming important 
Table 1. Some chemical parameters of seawater quality standard for marine life under the state of the environment minister's decision No. 51 of 2004

\begin{tabular}{lcc}
\hline \multicolumn{1}{c}{ Parameters } & Units & $\mathrm{KLH}$ standard \\
\hline $\mathrm{pH}$ & - & $7-8.5$ \\
Dissolved Oxygen (DO) & $\mathrm{mg} / \mathrm{L}$ & $>5$ \\
${\mathrm{P}-\mathrm{PO}_{4}}$ & $\mathrm{mg} / \mathrm{L}$ & 0.015 \\
$\mathrm{~N}-\mathrm{NO}_{3}$ & $\mathrm{mg} / \mathrm{L}$ & 0.008 \\
Si-Silicates & $\mathrm{mg} / \mathrm{L}$ & -
\end{tabular}

fishing grounds because they offer high primary and secondary productivity, which is supported by high nutrient concentrations [1]. Based on data from Bappeda Bintan in 2007, Tambelan livelihoods are dominated by fishing, which is $83.67 \%$.

Tambelan islands have the potential diversity of coral reefs, which are relatively high, but vulnerable to demolition using explosive devices activities conducted by fishermen who came from outside this area. Tambelan islands society is generally located in the vicinity of coastal waters and commonly caught fish are species of reef fish and small pelagic fish. The Bintan regency government in its efforts to maintain sustainable fishing activities intended to make Tambelan islands waters as marine protected areas (KKLD) by the issuance of Bintan Regent Decree No. 261/VIII/2007 dated 23 August 2007. The Candidate for protected areas covering 357,000 hectares.

To find out whether a water area is potential for fish catchment moreover as a conservation area, a study of water quality is certainly required for that purposes and to ascertain whether the conditions of waters capable for supporting breeding of fish and marine life in it or not? As generally known, human activities have already negatively influenced water quality and aquatic ecosystem functions. This situation has generated great pressure on these ecosystems, resulting in a decrease of water quality and biodiversity, loss of critical habitats, and an over-all decrease in the quality of life of local inhabitants [2]. A water quality parameter being close to or far from the limit allowed by the authorities has equal importance for the evaluation of the concentration of the parameters [3]. Chemical parameters such as degree of acidity $(\mathrm{pH})$, dissolved oxygen (DO), and nutrient content such as phosphate, nitrate, and silicate can be used as indicators of water quality. Moreover $\mathrm{pH}$ and oxygen play an important role in the process of metabolism and respiration of biota, while nutrients act as major components for growth and development of marine organisms.

Dissolved inorganic nutrients like phosphate, nitrate and silicate are chemical compounds that are easily absorbed by the phytoplankton to grow and develop, so the high and low abundance of phytoplankton in the territorial waters are depending on the concentration of nutrients in these waters [4-5]. In the other hand, limited nutrient (especially nitrogen and iron) availability led to impaired growth and proliferation of phytoplankton $[4,6]$. Otherwise in a state of nutrients excess can lead to explosive growth and dominance of certain species that may be harmful to aquatic ecosystems.

In seawater ecosystem food chain, phytoplankton is the initiators of the cycle. Phytoplankton is a food source for zooplankton, zooplankton are a source of food for small fish, small fish are a food source for larger fish and so on so that the abundance of phytoplankton will determine the abundance of fish. However, a plenty amount of nutrients is not always done well. In addition to its dominance of phytoplankton growth due to nutrient that is too abundant, the condition of hypoxia (decreased oxygen content) can ultimately occur and lead to mass mortality of fish. In other words the composition and abundance of nutrients in the water can affect the biodiversity. The Indonesian Ministry of Environment/KLH [7] has determined the seawater quality standard for marine life whose value as listed in Table 1.

\section{EXPERIMENTAL SECTION}

\section{Materials}

Sampling activity took place from 4-16 November 2010 in the waters of Tambelan islands. For chemical analysis, samples of seawater were collected from 12 points in the Tambelan islands station at 2 depths, the surface layer and the layer near the base.

\section{Instrumentation}

Seawater samples kept in Niskin bottles of $10 \mathrm{~L}$, which was operated by CTD (ConductivityTemperature-Depth) instruments and instrument of MBT (Mechanical Bathy Thermograph) manufactured by Sea-Bird Inc. Chemical parameters such as the degree of acidity $(\mathrm{pH})$, dissolved oxygen, and dissolved inorganic nutrient content of phosphate, nitrate and silicate were analyzed within six hours after the sea waters-sampling process.

The dissolved oxygen content (Dissolved Oxygen/DO) was estimated by DO meter of Mi-605 portable DO meter type of Martini instruments NCRocky Mountain, While the variable $\mathrm{pH}$ was measured using a pH meter of $826 \mathrm{pH}$ mobile series of MetrohmSwitzerland. The UV Spectrophotometer from Shimadzu Co series of UV-1201V was also used for measuring nitrate, phosphate and silicate parameters. 
Table 2. The data of dissolved inorganic nutrient (phosphate, nitrate and silicate), $\mathrm{pH}$, and dissolved oxygen (DO) in waters of the Tambelan Islands, 2010

\begin{tabular}{|c|c|c|c|c|c|c|c|c|c|c|}
\hline \multirow{3}{*}{ Station } & \multicolumn{6}{|c|}{ Concentration (mg/L) } & \multirow{2}{*}{\multicolumn{2}{|c|}{$\mathrm{pH}$}} & \multirow{2}{*}{\multicolumn{2}{|c|}{$\frac{\mathrm{DO}}{(\mathrm{mg} / \mathrm{L})}$}} \\
\hline & \multicolumn{2}{|c|}{$\mathrm{P}-\mathrm{PO}_{4}$} & \multicolumn{2}{|c|}{$\mathrm{N}-\mathrm{NO}_{3}$} & \multicolumn{2}{|c|}{ Si-Silicate } & & & & \\
\hline & surface & base & surface & base & surface & base & surface & base & surface & base \\
\hline 1 & 0.001 & 0.001 & 0.011 & 0.007 & 0.096 & 0.134 & 8.06 & 8.14 & 6.00 & 5.91 \\
\hline 2 & 0.004 & 0.003 & 0.013 & 0.009 & 0.108 & 0.111 & 8.14 & 8.22 & 6.23 & 5.92 \\
\hline 3 & 0.001 & 0.001 & 0.008 & 0.010 & 0.126 & 0.134 & 8.20 & 8.21 & 6.12 & 5.81 \\
\hline 4 & 0.001 & 0.001 & 0.007 & 0.006 & 0.123 & 0.108 & 8.22 & 8.22 & 6.25 & 6.04 \\
\hline 5 & 0.003 & 0.002 & 0.009 & 0.005 & 0.102 & 0.099 & 8.08 & 8.21 & 5.91 & 5.99 \\
\hline 6 & 0.001 & 0.001 & 0.008 & 0.005 & 0.117 & 0.108 & 8.14 & 8.18 & 6.01 & 5.78 \\
\hline 7 & 0.001 & 0.001 & 0.006 & 0.006 & 0.114 & 0.102 & 8.22 & 8.24 & 6.22 & 6.05 \\
\hline 8 & 0.004 & 0.001 & 0.008 & 0.010 & 0.090 & 0.096 & 8.19 & 8.26 & 5.26 & 5.62 \\
\hline 9 & 0.001 & 0.001 & 0.007 & 0.006 & 0.099 & 0.126 & 8.18 & 8.30 & 6.06 & 5.82 \\
\hline 10 & 0.001 & 0.002 & 0.006 & 0.007 & 0.099 & 0.093 & 8.15 & 8.19 & 5.95 & 6.17 \\
\hline 11 & 0.003 & 0.002 & 0.006 & 0.018 & 0.078 & 0.117 & 8.19 & 8.27 & 6.04 & 5.71 \\
\hline 12 & 0.002 & 0.001 & 0.005 & 0.005 & 0.081 & 0.063 & 8.18 & 8.23 & 6.31 & 6.08 \\
\hline Min. & 0.001 & 0.001 & 0.005 & 0.005 & 0.078 & 0.063 & 8.06 & 8.14 & 5.26 & 5.62 \\
\hline Max. & 0.004 & 0.003 & 0.013 & 0.018 & 0.126 & 0.134 & 8.22 & 8.30 & 6.31 & 6.17 \\
\hline Ave. & 0.002 & 0.001 & 0.008 & 0.008 & 0.102 & 0.107 & 8.16 & 8.22 & 6.03 & 5.91 \\
\hline
\end{tabular}

\section{Procedure}

The measurement of nitrate content of seawater in the Tambelan islands is based on methods developed by Morris and Riley in 1963 and then modified by Strickland and Parsons in 1968 [8]. In this method nitrate is reduced to nitrite using cadmium-copper column. The resulting nitrite reacts with sulfanilamide in acid solution to produce diazonium compound which also bound with $\mathrm{N}$-(1-Naphthyl)ethylenediaminedihydrochloride to form a colored azo dye. This colored compound can be measured using spectrophotometric method with detection limits of $0.0007 \mathrm{mg} / \mathrm{L}$ at $543 \mathrm{~nm}$ a wavelength.

Meanwhile, the measurement of phosphate levels (reactive phosphorus) is also based on the method developed by Strickland and Parsons in 1968. In this method samples of seawater reacts with the combined reagent containing ammonium molybdate, ascorbic acid and potassium-tartrate antimonyl to form complex bluish solution, which also can be measured using spectrophotometric method at a wavelength $885 \mathrm{~nm}$ with detection limits of $0.0003 \mathrm{mg} / \mathrm{L}$. Similarly to previous procedure, the content of silicate in seawater will also measured based on methods that have been developed by Strickland and Parsons in 1968. By this method, seawater sample is reacted with ammonium molybdate followed by shaking/stirring to generate complex silicomolybdate, phospomolybdate and arsenomolybdate. After then methol reducing agent and oxalic acid are added, so that silicomolybdate reduces to silicomolybdous acid with a bluish color formation. Color changes that occur in this process are subsequently measured by spectrophotometric method with detection limits of $0.002 \mathrm{mg} / \mathrm{L}$ at a wavelength $810 \mathrm{~nm}$ and will be used as the basis for determining the content of silicate in seawater.

\section{RESULT AND DISCUSSION}

State of the chemical properties of the waters around the Tambelan islands are closely related to the condition of waters in the area of macro surrounding waters. Due to the condition of water sampling (sampling condition) conducted in November (wet/rainy season), so the state of the Tambelan islands waters will greatly influenced the waters trend from the South China Sea (Fig. 2).

pH

Since the start of the Industrial Revolution, $\mathrm{pH}$ of sea surface has decreased by about $0.1 \mathrm{pH}$ unit [9], and it is predicted to decrease by another $0.3-0.4 \mathrm{U}$ (corresponding to a $100-150 \%$ increase in the concentration of $\mathrm{H}^{+}$ions) by 2100 under the IS92a scenario [10]. The global atmospheric concentration of $\mathrm{CO} 2$ increased significantly from the pre-industrial value of about $280-379 \mathrm{ppm}$ in 2005 and it has exceeded the natural range over the last 650,000 years [11]. To date, about $42 \%$ of the anthropogenic $\mathrm{CO}_{2}$ emissions have been taken up by the ocean [12]. Those conditions as well lead the dynamics of $\mathrm{pH}$ in seawater.

$\mathrm{pH}$ variations that are exceed the normal range in seawater can affect the metabolism of biota and other sea creatures as well as the growth of microalgae and the balance of inorganic carbon. In general, the change of nutrient availability can affect cell physiology. 


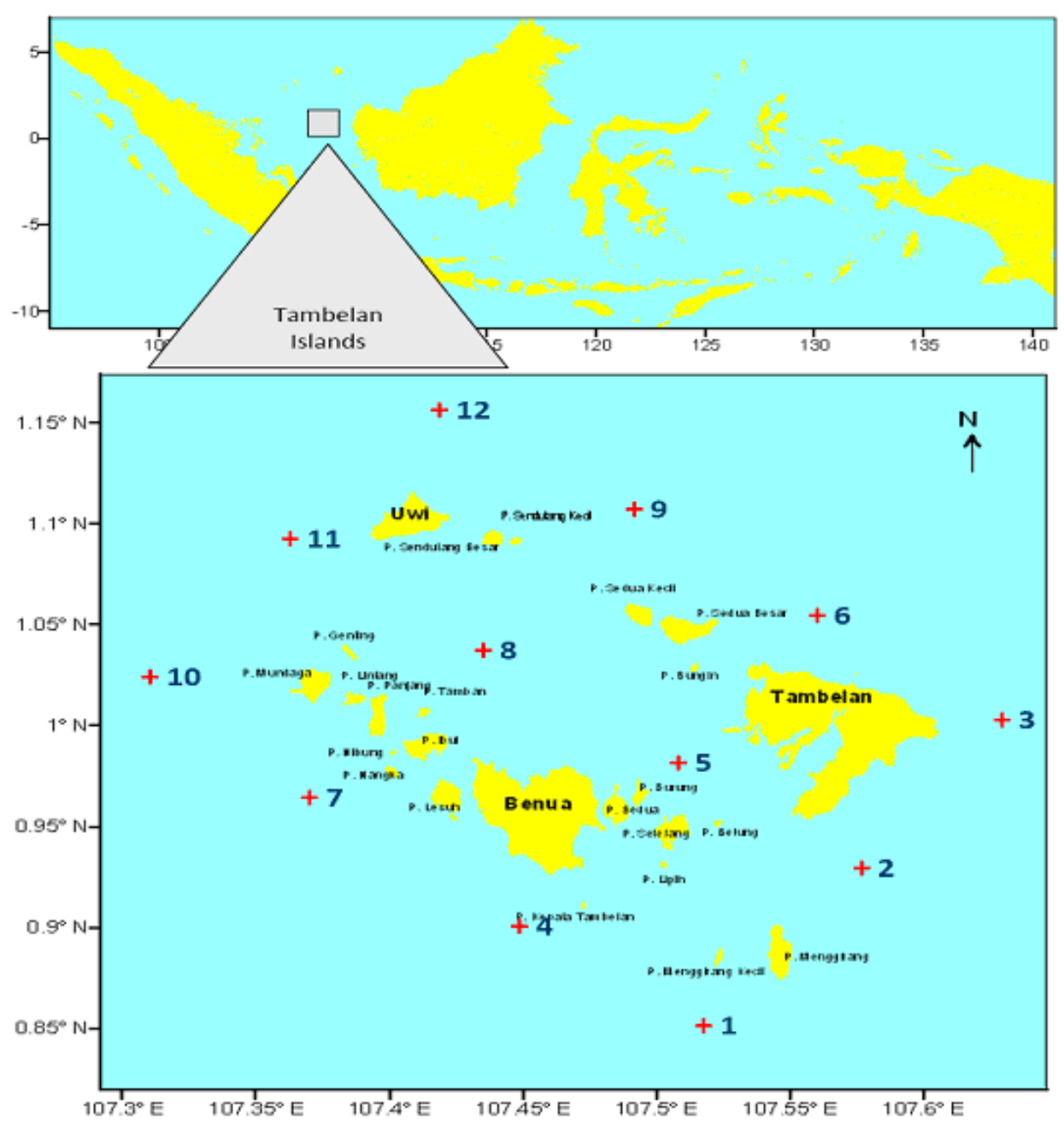

Fig 1. 12 stations sampling at Tambelan islands

For Tambelan waters, the data obtained from the measurement of $\mathrm{pH}$ value was in range of 8.06 to 8.30 (see Table 2). This result is in agreement with the data of $\mathrm{pH}$ in the waters of the South China Sea during the last 7000 years is about 7.91 to 8.29 [13].

\section{Dissolved Oxygen (DO)}

Dissolved oxygen (DO) is a very important variable in aquatic ecosystems (including marine), particularly essential for the process of respiration for most organisms and living beings. Raymont [14] stated that several factors that affect the entry of oxygen from the air including water saturation, temperature, salinity, water and air mass movements such as currents, waves and tides.

The range of dissolved oxygen in waters of Tambelan was measured and amounted to 5.26 to 6.31 $\mathrm{mg} / \mathrm{L}$. High oxygen content and almost homogeneous distributed is not surprising regarding the water conditions are quite clear, which indicates the low amount of suspended solids, so that water has a greater ability to dissolve oxygen. In addition, the level of water clarity makes the penetration of sunlight into water column becomes easier so can reach the deeper areas, and will increase the possibility of phytoplankton to use it as a source of energy for the process of photosynthesis and oxygen production. From the Table 2 it is observed that the lowest oxygen content (both on the surface and near the base) is found at station 8 . These data indicate that at station 8 there is a process of decomposition of organic materials near the sediment that requires quite a lot of oxygen, thus impact the color of clay sediments that became more blackish as a result of the mineralization [15].

In general, dissolved oxygen in surface waters is greater than near the base. This condition is not surprising considering the surface layer is the layer that directly interacting with the atmosphere. In addition, it is known that phytoplankton usually produce oxygen on 


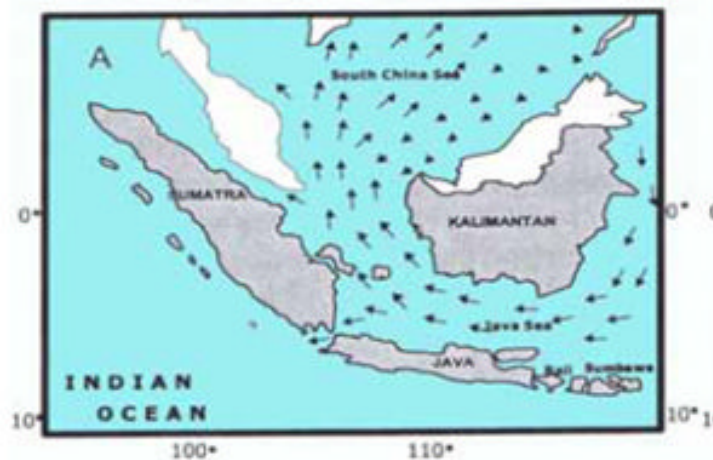

(a)

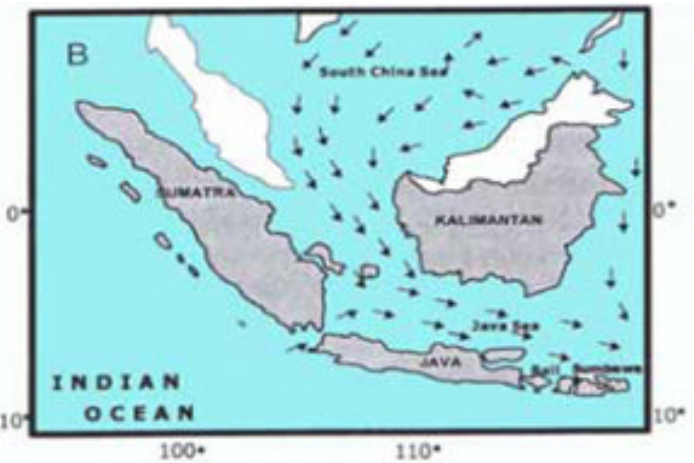

(b)

Fig 2. The ocean currents circulation during the dry season (a) and wet season (b) in the region of the South China and Java sea [28]

the surface of the water due to the sunlight is needed as an energy source is available in this layer.

\section{Phosphate and Nitrate}

Phosphorus occurs particularly as phosphate in aquatic systems. Phosphate is involved in a wide variety of biological and chemical processes in natural waters, wastewater, and water treatment. In seawater, phosphate is an important element for organisms [1617]. The number of nutrients (including phosphate) resulted in proliferation of plant growth and marine microorganisms, particularly macrophyta and phytoplankton [4]. Phosphate derived primarily from the sediment then would be filtrated in seawater and finally went into open water systems [18]. In addition, phosphate can also be introduced from the atmosphere with rainwater into the aquatic system considering that atmospheric inputs are a major route by which some key nutrients for phytoplankton growth reach the ocean [19].

Besides phosphate, nitrate is an essential nutrient for aquatic plants and animals. Marine biogeochemical cycling can affect atmospheric $\mathrm{N}$ deposition [20-21]. Atmospheric inorganic nitrogen is emitted naturally via ammonia and nitrous oxide from soils, plants and animal wastes as nitrogen source for phytoplankton in both seawater and freshwater [22]. Another combination form of nitrogen such as ammonia, nitrite and organic compounds can be used if shortage of nitrate in the water occurs. Another thing associated to the content of nitrate in the seawater is, the high content of nitrate can be used as an indicator of pollution in the region. Table 2 states the content of phosphate and nitrate levels in the Tambelan islands waters. Phosphate content was in the range of 0.001 to $0.004 \mathrm{mg} / \mathrm{L}$. This value indicated that the quality of the waters is relatively under natural conditions.

This condition becomes a positive motivating factor for the development of fisheries and other marine commodities (clams, shrimp, etc.). As for nitrate, the concentration is ranged from 0.005 to $0.018 \mathrm{mg} / \mathrm{L}(5-18$ $\mathrm{ppb})$. According to Sharp [23], this value shows that the waters around in the location of the study area still showed a normal conditions/natural, because the values are obtained with in the range of 0-30 ppb.

The content of phosphate and nitrate in Tambelan islands waters has a different distribution pattern between the surface water and the layer near the bottom. The pattern in the surface layer is more regular, while in the layer near the base is more random. The lack of the nutrient distribution patterns in the area near the base was observed because of differences in nutrient exchange interaction watersediments due to differences in sediment substrate. Meanwhile, the similar distribution pattern of phosphate and nitrate compounds in Tambelan islands is that the content of these two compounds were found to be higher in the strait as seen in the data in Table 2 compile with Fig. 1.

\section{Silicate}

In addition like phosphate and nitrate, silicate can also be used as an indicator of water quality [24-25]. At the moment where all nutrients required for phytoplankton growth and development are met, the availability of silicate plays a role in determining the competition and the dominance of algae species and phytoplankton. Tsunogai [26] in his hypothesis described 2 stages of the development of phytoplankton as follows. Initially in a warm environment and contain enough nutrients possibilities, diatom population will grow rapidly and begin to dominate the territorial waters, causing the concentration of silicate in the region decreased more rapidly than other nutrients. Secondly, in case the concentration of silicate is less than $5-10 \mu \mathrm{mol} \mathrm{Si/L}$, equivalent to 0.14 to $0.28 \mathrm{mg} / \mathrm{L}$, then diatom population 
growth will halt and begin to be replaced by other types of phytoplankton such as dinoflagellates that do not require silicate for growth, but can exist with utilize the remaining nutrients.

The concentration of silicate in the surface layer of the Tambelan islands waters were in the range of 0.078 to $0.126 \mathrm{mg} / \mathrm{L}$ with an average of $0.102 \mathrm{mg} / \mathrm{L}$. On the other hand, data from the layer near the bottom area shows silicate concentrations ranged from 0.063 to $0.134 \mathrm{mg} / \mathrm{L}$ with an average of $0.107 \mathrm{mg} / \mathrm{L}$.

As like phosphate and nitrate, silicate content in the Tambelan islands also has a similar distribution pattern which the value will increasing from the North to the South, and the highest silicate content was observed at the research stations located in the strait.

\section{CONCLUSION}

Based on the investigation results of the chemical parameters such as $\mathrm{pH}$, dissolved oxygen and nutrients such as phosphate, nitrate, and silicate; water conditions in the Tambelan islands relatively unspoiled and quite good because it meets the sea water quality standard for marine biota issued by the Ministry of Environment Republic of Indonesia and also meets the sea water quality standard for protection of coastal areas and estuaries ASEAN region. However, low silicate concentration should really pay attention because it can lead to the emergence and phytoplankton population growth is harmful to the aquatic environment. Finally, these good water qualities would provide great opportunities for Tambelan islands to be developed as a marine national park or marine conservation area which one of the conditions is able to guarantee the long-term conservation of the natural resources that exist in it [27].

\section{ACKNOWLEDGEMENT}

This research was financially supported by joint project of DP2M-DIKTI and LIPI (Indonesian Institute of Science). Many thanks also to Particular Ship Research Vessel BARUNA JAYA VIII and all crew for the support and facilitation.

\section{REFERENCES}

1. Wei, H., Su, J., Wan, R., Wang, L., and Lin, Y., 2003, Fish. Oceanogr., 12, 4-5, 434-442.

2. Herrera-Silveira, J.A., and Morales-Ojeda, S.M., 2009, Mar. Pollut. Bull., 59, 1-3, 72-86.

3. Wu, M.L., Wang, Y.S., Sun, C.C., Wang, H., Dong, J.D., Yin, J.P., and Han, S.S., 2010, Mar. Pollut. Bull., 60, 6, 852-860.
4. Gardner, E.M., McKnight, D.M., Lewis Jr., W.M., and Miller, M.P., 2008, Arct. Antarct. Alp. Res., 40, $1,55-64$.

5. Drake, J.L., Carpenter, E.J., Cousins, M., Nelson, K.L., Zarate, A.G., and Loftin, K., 2010, Hydrobiologia, 654, 177-192.

6. Piehler, M., Twomey, L.J., Hall, N.S., and Paerl, H.W., 2004, Estuarine, Coastal and Shelf Science, vol. 61 , pp. 197-209.

7. Indonesian Ministry of Environment/KLH, 2004, Baku Mutu Air Laut untuk Biota Laut, Lampiran III Keputusan Menteri Negara Lingkungan Hidup No.51/2004,

http://hukum.unsrat.ac.id/men/menlh_51_2004_3.p df, accessed at December 6, 2011.

8. Strickland, J.D.H., and Parsons, T.R., 1968, A Practical Handbook of Seawater Analysis, Fisheries Research Board of Canada Bulletin 167.

9. Caldeira K., and Wickett M.E., 2003, Nature, 425, 365.

10. Orr, J.C., Fabry, V.J., Aumont, O., Bopp, L., Doney, S.C., Feely, R.A., Gnanadesikan, A., Gruber, N., Ishida, A., Joos, F., Key, R.M., Lindsay, K., MaierReimer, E., Matear, R., Monfray, P., Mouchet, C.L., Najjar, R.G., Plattner, G.K., Rodgers, K.B., Sabine, C.L., Sarmiento, J.L., Schlitzer, R., Slater, R.D., Totterdell, I.J., Weirig, M.F., Yamanaka, Y., and Yool, A., 2005, Nature, 437, 681-686.

11. Intergovernmental Panel on Climate Change, Fourth Assessment Report: Climate change: Synthesis Report, 2007.

12. Sabine, C.L., Feely, R.A., Gruber, N., Key, R.M., Lee, K., Bullister, J.L., Wanninkhof, R., Wong, C.S., Wallace, D.W.R., Tilbrook, B., Millero, F.J., Peng, T.H., Kozyr, A., Ono, T., and Rios, A.F., 2004, Science, 305, 5682, 367-371.

13. Liu, Y., Liu, W., Peng, Z., Xiao, Y., Wei, G., Sun, W., He, J., Liu, G., and Chou, C.L., 2009, Geochim. Cosmochim. Acta, 73, 1264-1272.

14. Raymont, J.E.G., 1963, Plankton and productivity in the oceans, Pergamon press, Oxford, p. 660.

15. Dauwe, B., Middelburg, J.J., and Herman, P.M.J., 2001, Mar. Ecol. Prog. Ser., 215, 13-22.

16. Okamoto, T., Fukushi, K., Takeda, S., and Wakida, S., 2007, Electrophoresis, 28, 19, 3447-3452.

17. Chitrakar, R., Tezuka, S., Sonoda, A., Sakane, K., Ooi, K., and Hirotsu, T., 2006, J. Colloid Interface Sci., 297, 2, 426-433.

18. Haggard, B.E., Ekka, S.S., Matlock, M.D., and Chaubey, I., 2004, Trans. ASABE, 47, 4, 11131118.

19. Jickells, T.D., 2002, Emissions from the oceans to the atmosphere, deposition from the atmosphere to the oceans and the interactions between them, 
Challenges of a Changing Earth, edited by W. Steffen et al., Springer, New York, 93-96.

20. Krishnamurthy, A., Moore, J.K., Zender, C.S., and Luo, C., 2007, J. Geophys. Res., 112, 1-10.

21. Zhang, Y., Yu, Q., Ma, W., and Chen, L., 2010, J. Geophys. Res., 115, 1-10.

22. Jickells, T.D., 2005, J. Sea Res., 54, 1, 58-69.

23. Sharp, J.H., 1983, The distribution of inorganic nitrogen and dissolved particulated organic nitrogen in the sea, in Nitrogen in The Environment, Academic press, New York, 1-29.

24. Owili, M.A., 2003, Assesment of impact on sewage effluents on coastal water quality in Hafnarfjordur, UNU-Fisheries Training Programme, Iceland, 1-39.
25. Leparc, J., Rapenne, S., Courties, C., Lebaron, P., Croue, J.P., Jacquemet, V., and Turner, G., 2007, Desalination, 203, 1-3, 243-255.

26. Tsunogai, S., 1979, Bulletin Faculty Fisheries Hokkaido University, 30, 314-322.

27. Wiryawan, B, 2006, Kawasan konservasi laut sebagai instrumen pengelolaan perikanan tangkap: pembelajaran dari Kabupaten Berau, Kalimantan Timur, Scientific Repository-Bogor Agriculture University, 95-113.

28. Damar, A. 2003, Effects of enrichment on nutrient dynamics, phyto-plankton dynamics and productivity in Indonesian tropical waters: A Comparison between Jakarta Bay, Lampung Bay and Semangka Bay, Dissertation, ChristianAlbrecht University, Kiel, p. 235. 